\title{
DISKURSUS MEDIASI DAN UPAYA PENYELESAIANNYA
}

\author{
Karmawan \\ Universitas Islam Syekh Yusuf (UNIS) Tangerang \\ Jln Maulana Yusuf No. 10, Kota Tanggerang Banten 15118 \\ Email: karmawanma@gmail.com
}

\begin{abstract}
Mediation Discourse and Its Settlement Efforts. Mediation provides cultural values in society and upholds the eastern values of the prior art of consensus deliberation. Related to Islamic law, an attempt to reconcile the disputants is the command of Allah Swt. and Rasulullah Saw. to mankind. It aims to make people always face problems with cold head and not with violence so that the creation of tranquility in human life, especially problems in society and family. Even the principles and values of peace derived from the traditions of Islamic teachings, it will be able to resolve the conflicts, both in social and political fields.
\end{abstract}

Keywords: Mediation, Problems, Positive Law

\begin{abstract}
Abstrak: Diskursus Mediasi dan Upaya Penyelesaiannya. Mediasi memberikan nilainilai budaya dalam masyarakat dan menjunjung tinggi nilai-nilai ketimuran yang lebih medahulukan musyawarah mufakat. Terkait hukum Islam, upaya mendamaikan orang-orang yang bersengketa merupakan perintah Allah Swt. dan Rasulullah Saw. kepada umat manusia. Hal ini bertujuan agar manusia selalu menghadapi permasalahan dengan kepala dingin dan bukan dengan kekerasan sehingga terciptanya ketentraman dalam kehidupan manusia, khususnya permasalahan dalam masyarakat maupun keluarga. Bahkan prinsip dan nilai damai yang diderivasi dari tradisi ajaran Islam, akan mampu menyelesaikan konflik, baik dalam lapangan sosial maupun politik.
\end{abstract}

Kata kunci: Mediasi, Permasalahan, Hukum Positif

\section{Pendahuluan}

Mediasi merupakan bentuk penyelesaian sengketa di luar pengadilan yang dewasa ini digunakan pengadilan sebagai proses penyelesaian sengketa. Pengintegrasian mediasi ke dalam proses beracara di Pengadilan memiliki potensi sebagai sarana untuk menyelesaikan sengketa yang lebih ekonomis baik dari sudut pandang biaya maupun waktu. Memberikan manfaat 
kepada para pihak yang bersengketa dengan win-win solution, ${ }^{1}$ bukan kalah menang (win-lose). Selain itu, proses mediasi di Pengadilan diharapkan dapat mengatasi masalah penumpukan perkara. ${ }^{2}$ Pasca diberlakukannya Peraturan Mahkamah Agung Nomor 1 Tahun 2008 tentang prosedur mediasi di Peradilan, mediasi telah menjadi salah satu rangkaian penting dari keseluruhan proses penanganan perkara di pengadilan, termasuk Pengadilan Agama. ${ }^{3}$ Adanya klausul-klausul yang beraksentuasi imperatif, seperti kemestian melakukan proses mediasi sebelum pemeriksaan pokok perkara, kemungkinan batalnya putusan pengadilan yang tidak menyertakan pertimbangan mediasi, dan berbagai klausul lainnya mendorong perhatian terhadap mediasi menjadi semakin intensif. ${ }^{4}$

Mediasi yang dilaksanakan Pengadilan Agama merupakan perwujudan kekuasaan kehakiman dalam proses penyelesaian sengketa secara damai. Sebagai penyelenggara kekuasaan kehakiman, Pengadilan Agama tentunya mempunyai tugas pokok untuk membantu pencari keadilan dalam menerima, memeriksa, mengadili dan menyelesaikan perkara yang diajukan kepadanya, dengan berpegang teguh pada prinsip asas sederhana, cepat dan biaya murah. Semenjak berlakunya Undang-undang Nomor 3 Tahun 2006 tentang Perubahan atas Undang-undang Nomor 7 Tahun 1989 mengenai Peradilan Agama, maka menjadikan kewenangan Pengadilan Agama semakin luas dan kompleks. ${ }^{5}$

${ }^{1}$ Principal or decisionmakar is mandated to participate in the Process. Robert E. Margulies, "How To Win In Mediation" (New Jersey Lawyer, The Magazine, 2002), h.66.

${ }^{2}$ Court generally see settlement as an absolute necessity to process all their cases, and judges often look to mediation as a way to relieve caseload pressures. Jhon Lande, "Prosedure for Building Quality Into Court Mediation Programs", Alternatives to the High Cost of Litigation, 2005, h. 22

${ }^{3}$ Anonimous, Buku komentar Peraturan Mahkamah Agung RI No. 01 Tahun 2008 tentang Pelaksanaan Mediasi di Pengadilan. Dibuat atas kerjasama MARI, Japan International Cooperation Agency (JICA) dan Indonesia Institute for Conflict Transformation (IICT), 2008, h. 7-12.

${ }^{4}$ Semangat yang menginspirasi perlunya mediasi dalam pemeriksaan perkara di pengadilan adalah kenyataan bahwa perdamaian, jika mediasi berhasil, memiliki akibat hukum dan efek psikologis yang sangat baik bagi pihak-pihak berperkara karena dihasilkan dari kesepakatan pihakpihak sendiri, sehingga daya ikatnya terhadap penyelesaian perkara menjadi lebih kuat, dan oleh karenanya kemungkinan untuk mengajukan proses hukum lebih lanjut semakin menipis, dan bagi pengadilan dapat mengurangi penumpukan perkara. Pasal 2 Ayat (3) Perma No.1 Tahun 2008 tentang Prosedur Mediasi di Pengadilan.

${ }_{5}^{5}$ Dalam Pasal 49 Undang-undang Nomor 3 Tahun 2006 menyatakan bahwa "Pengadilan Agama bertugas dan berwenang untuk memeriksa, memutus dan menyelesaikan perkara-perkara antara lain yang berhubungan dengan:(a) perkawinan; (b)waris; (c)waris; (d)hibah; (e)wakaf; (f) zakat; (g)infaq; (h)shadaqah; (i)Ekonomi syariah. 


\section{Pelaksanaan Mediasi}

Di Indonesia, apabila dilihat secara mendalam, penyelesaian sengketa secara damai telah lama dan biasa dilakukan masyarakat Indonesia. Hal ini dapat dilihat dari hukum adat yang menempatkan kepala adat sebagai tokoh yang dapat menyelesaikan sengketa di antara warganya. Penyelesaian sengketa secara damai juga dikenal dalam hukum Islam, dimana Islam mengajarkan agar pihak-pihak yang bersengketa melakukan perdamaian. ${ }^{6}$ Islam selalu menyuruh menyelesaikan setiap persengketaan melalui alshulh 7 Begitu juga, dikalangan masyarakat Cina di Indonesia dijumpai cara penyelesaian sengketa secara damai dengan Confucius yang menekankan hubungan yang harmonis antara manusia dan manusia serta manusia dan alam. Pandangan ideal dari kaum Confucian menganggap penyelesaian sengketa diluar pengadilan lebih baik daripada didepan, karena pengadilan hanya untuk orang-orang yang nakal atau jahat. Dengan demikian, mediasi dan konsiliasi adalah jalan untuk mendapatkan keadilan yang ideal dalam menyelesaikan sengketa. ${ }^{8}$

Di Indonesia, perkara perdata Islam yang menganut agama Islam diselesaikan oleh Pengadilan Agama. Hakim Pengadilan Agama, sebelum tahun 1974, memutus perkara berdasarkan hukum Islam yang bersumber dari 13 kitab fikih yang ditentukan oleh Departemen Agama. ${ }^{9}$ Serelah berlakunya UU No. 1 Tahun 1974 tentang perkawinan, hakim Pengadilan Agama memutus perkara perkawinan berdasarkan hukum Islam yang terdapat dalam kitab fikih dan undang-undang perkawinan. ${ }^{10}$ Pada tahun

\footnotetext{
${ }^{6}$ Q.S. Al-Nisa (4): 128.

${ }^{7}$ Secara bahasa ishlah asal kata dari al-Shulh merupakan lawan dari kata "permusuhan" (khilaf al-mukhâshamah), lawan dari kata "kerusakan" (dhiddu fasâd). Luis Mảluf, al-Munjid fi al-Lughah wa al-A'làm (Beirut: Dâr al-Masyriq, 1986), Cet. XXVIII, 432. Sedangkan dalam terminologi fikih, al-shulh diartikan sebagai suatu akad/perjanjian untuk menghapuskan persengketaan secara sukarela dari kedua belah pihak yang bersengketa, dengan persyaratan adanya ijab dan kabul dari masing-masing pihak, Sầ̂ Abî Jaib, al-Qâmûs al-Fiqhî̀ Lughatan wa istilâhan (Damaskus: Dâr al-Fikr, 1998), Cet. I, h.215.

${ }^{8}$ Percy R. Luney, Jr, "Traditions an Foreign Influences: Systems of Law in China and Japan," Dalam Journal Law and Contemporary Problems (Caroline: Duke University School of Law, 1987), Vol. 52, No. 2, h.130.

${ }^{9}$ Depatemen Agama, Himpunan Putusan Penetapan Pengadilan Agama (Jakarta: Badan Peradilan Agama, 1978/1979) memuat putusan-putusan Pengadilan Agama dan Pengadilan Tinggi Agama tahun 1957 s/d 1966 yang sumber hukumnya merujuk pada kitab-kitab fikih.

${ }^{10}$ Departemen Agama, Himpunan Putusan Pengadilan Tinggi Agama (Jakarta: Badan Peradilan Agama, 1982/1983) berisi putusan-putusan Pengadilan Tinggi Agama tahun 1979 s/d 1980 yang sumber hukum dalam putusan tersebut merujuk pada kitab-kitab fikih dan undang-undang Perkawinan Tahun 1974.
} 
1991, setelah terbitnya Kompilasi Hukum Islam (KHI) yang memuat kumpulan hukum Islam mengenai perkawinan, kewarisan, hibah, wasiat, dan wakaf, sumber hukum bagi hakim Pengadilan Agama dalam memutus perkara bukan hanya kitab fikih dan undang-undang perkawinan, namun ditambah dengan ketentuan hukum yang termaktub dalam kompilasi hukum Islam. ${ }^{11}$

Hal yang menarik penyelesaian melalui mediasi di Pengadilan Agama dalam memutus perkara, baik perkara yang menyangkut perceraian, sengketa waris, harta bersama dan sengketa ekonomi syari’ah. Mediasi yang dilaksanakan oleh Pengadilan Agama tersebut merupakan hukum yang diciptakan oleh Hakim untuk memberikan pertimbangan hukum terhadap pihak-pihak yang berperkara secara adil. Secara garis besar penyelesaian melalui mediasi yang dilaksanakan oleh Pengadilan Agama sebagai responsif rasa keadilan yang berkembang dalam masyarakat dibidang perkawinan, kewarisan, harta bersama dan sengketa ekonomi syari'ah baik dari aspek sumber hukum, substansi hukum dan tingkat responsifnya terhadap terhadap isu-isu keadilan dan perkembangan sosiologis masyarakat Islam kontemporer. ${ }^{12}$

Perdamaian sebagai sebuah akad pada pada dasarnya menurut mazhab Hanafi dapat terjadi dengan pengakuan atau diam sebagai tanda setuju atau dengan pengingkaran terhadap hal yang sebaliknya sehingga menyetujui hal yang lainnya. ${ }^{13}$ Dalam fikih perdamaian dibahas bersamaan dengan 'aqd (perjanjian), karena adanya kemungkinan terjadi perdamaian manakala terjadi perselisihan wanprestasi dalam 'aqd tersebut. ${ }^{14}$ Menurut Hamzah Muhammad Qâsim, Sulh atau perdamaian merupakan bagian dari aqad yang isinya mengakhiri sengketa. ${ }^{15} \mathrm{Al}-$

${ }^{11}$ Harun Alrasyid, ed. Himpunan Peraturan Perundang-undangan Republik Indonesia (Jakarta: PT. Ichtiar Baru Van Hoeve), Buku ke I, 861; dan Zainal Abidin Abubakar, Himpunan Peraturan Perundang-undangan dalam Lingkungan Peradilan Agama (Surabaya: Pengadilan Tinggi Agama Surabaya), h.361.

${ }^{12}$ Masykuri Abdillah mengintrodusir dua kategori hukum yakni hukum substansial dan hukum esensial. Hukum substansial mengacu pada materi hukum Islam, sedangkan hukum esensial mengacu pada prinsip-prinsip dan moralitas hukum Islam. Masykuri Abdillah dkk., Formalisasi Syariat Islam di Indonesia sebagai sebuah Pergulatan yang Tak Pernah Tuntas (Jakarta: Renaisan, 2005),h. 327.

${ }^{13}$ Muhammad Ibn Husayn Ibn 'Ali al-Turi al-Qadiri al-Hanafi, al-Bahr al-Raiq, Juz VII,h. 434.

${ }^{14}$ Wanprestasi adalah tidak memenuhi sesuatu yang diwajibkan seperti yang telah ditetapkan dalam perikatan, Abdul Kadir Muhammad, Hukum Perdata Indonesia, h.205.

${ }^{15}$ Hamzah Muhammad Qasim, Manar al-Qârî Sharh Sahih Bukhari, Juz III (Beirut: Maktabah Dar al-Bayan, 1990), h.51. 
Zuhayli menjelaskan tentang hukum dari perdamaian adalah sunnah, seorang hakim dianjurkan untuk mengupayakan damai tetapi ia tidak boleh memaksakan perdamaian tersebut kepada para pihak yang bersengketa. Menurut al-Zuhayli, adanya pembahasan sulh dalam akad karena sulh dapat mengandung beberapa makna yaitu: jual beli, hibah, sewa menyewa, pinjam meminjam, ibrâa (melepaskan hak) atau juga salam. Kedekatan makna sulh dengan akad-akad tersebut, sesuai dengan terjadinya sulh. Apabila perdamaian terjadi pada permasalahan jual-beli, maka sulh akan bermakna jual beli. ${ }^{16}$

Perdamaian dalam hukum acara perdata berawal dari kewajiban hakim untuk mendamaikan pihak yang bersengketa berdasarkan Pasal 130 HIR dan 149 RBg, Pasal 1851 KUHP Perdata. Saat ini perdamaian sudah menjadi bagian penting dari hukum acara perdata yang dikemas dalam bentuk mediasi. Mediasi lebih menekankan pada keberadaan pihak ke tiga yang menjembatani para pihak bersengketa untuk menyelesaikan sengketa yang dihadapi. ${ }^{17}$ Mediasi selain dikenal dalam lingkungan peradilan, juga dikenal dalam bentuk penyelesaian secara sukarela seperti yang dikembangkan oleh Badan Pertanahan Nasional untuk menyelesaikan sengketa tanah. ${ }^{18}$ Demikian juga mediasi dikenal dalam penyelesaian sengketa lingkungan hidup sesuai dengan Peraturan Pemerintah Nomor: 54 Tahun 2000. Mediasi berbeda dengan litigasi yang ingin memperoleh hasil akhir sesuai dengan hukum yang berlaku, berbeda pula dengan conseling karena landasan mediasi tidak berpijak pada faktor psikologis dan perilaku. Demikian pula mediasi berbeda dengan arbitrase, di mana posisi arbitrer ditunjuk untuk memberikan keputusan akhir. ${ }^{19}$

${ }^{16}$ Wahbah al-Zuhayli, al-Figh al-Islami wa Adillatuh, Juz VI, h.293-294.

${ }^{17}$ Syahrizal Abbas, Mediasi Dalam Perspektif Hukum Syariah Hukum Adat dan Hukum Nasional (Jakarta: Kencana, 2009),h. 3.

${ }^{18}$ Salah satu metode penyelesaian kasus pertanahan ditetapkan melalui mediasi dimana mekanisme pelaksanaan mediasi diatur di dalam Petunjuk Teknis Badan Pertanahan Nasional Republik Indonesia Nomor: 05/JUKNIS/ D.V/2007 (Keputusan Kepala BPN RI No. 34 Tahun 2007) Tentang Mekanisme Pelaksanaan Mediasi yang dikeluarkan di Jakarta pada tanggal 31 Mei 2007.

${ }^{19}$ Jhon Wade, Sekitar Mediasi (Jakarta: MARI, 2004), h. 158. 


\section{Mediasi dalam Sejarah Islam}

Mediasi dalam literatur Islam disamakan dengan tahkiîm. ${ }^{20}$ Tahkiîm dalam terminologi fikih ialah adanya dua orang atau lebih yang meminta orang lain agar diputuskan perselisihan yang terjadi di antara mereka dengan hukum syar'i. ${ }^{21}$ Tahkîm yakni berlindungnya dua pihak yang bersengketa kepada orang yang mereka sepakati dan setujui serta rela menerima keputusannya untuk menyelesaikan persengketaan mereka, berlindungnya dua pihak yang bersengketa kepada yang mereka tunjuk (sebagai penengah) untuk memutuskannya atau menyelesaikan perselisihan yang terjadi di antara mereka. ${ }^{22}$

Lembaga Tahkîm telah dikenal sejak jauh sebelum Islam. Orangorang Nasrani apabila mengalami perselisihan, mereka mengajukan perselisihan tersebut kepada Paus untuk diselesaikan secara damai. Tahkiîm juga dilakukan orang-orang Arab sebelum datangnya Islam. Pertikaian diantara mereka biasanya diselesaikan dengan menggunakan lembaga Tahkîm. Pada umumnya apabila terjadi perselisihan antar suku, maka kepala suku yang bersangkutan mereka pilih sebagai hakam-nya. Sedangkan jika persengketaan tersebut terjadi antar suku maka yang diangkat sebagai hâkam adalah kepala suku lain yang tidak terlibat sengketa tersebut. ${ }^{23}$ Meskipun belum terdapat sistem peradilan yang

${ }^{20}$ Tahkîm berasal dari kata kerja "hakkama-yuhakkimu-tahkîm" artinya menyerahkan

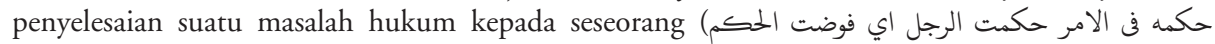
اليه. Ahmad ibn Muhammad ibn al-Maqri al-Fayûmi, Kitâb Misbâh al-Munîr fî Gharib al-Syarh al-Kabîr li al-Râfî, (Kairo: al-Mathba'at al-Amiriyyah li Wuzârat al-Ma'ârif al-'Umûmiyyah, 1968), Juz I, Cet. VII, 200; Muhammad Majduddin Muhammad ibn Yảqûb al-Fairûzabadî al-Qâmûs alMuhîth (Beirut: Dâr al-Jîl, t.th), Juz IV, 99; Dalam pengertian yang lain mencegah kerusakan atau mendamaikan (حكم اليتيم كما تحكم ولدك اى امنعه من الفساد واصلحه كما تصلح ولدك). Ibn al-Manzhûr, Lisân al-Arab (Kairo: Dâr al-Ma'ârif, t.th), Vol. II, 953; Yang juga bisa diartikan mengangkat seorang hakim (حكمه اى جعله حكما). Abdul Wahhâb al-Sayyid 'Iwadhullah dan Muhammad 'Abdul Aziz al-Qalamâwî (ed.), al-Mưjam al-Wasîth, (t.tp: Dâr al-Handasyyah, 1985), Juz I, Cet. III, 197; Tahkîm dikategorikan juga sebagai salah satu "Syibh al-Qadha" (quasi peradilan) selain wilayat alHisbah dan wilayat al-Madzhâlim, Muhammad Salâm Madkûr, al-Qadhâ fî al-Islâm (Kairo: Dâr al-Nahdhah, t.th.), h. 131.

${ }^{21}$ Samir Aliyah, Sistem Pemerintahan Peradilan dan Adat Dalam Islam (Jakarta: Khalifah, 2004), h. 328.

${ }^{22}$ Ensiklopedia Hukum Islam (Jakarta: PT Ichtiar Baru Van Hoeve, 2003), h. 1750.

${ }^{23}$ Ahmad S. Moussalli, An Islamic Model for Political Conflict Resolution: Tahkim (Arbitration)", dalam Abdul Aziz Said, Nathan C. Funk, Ayse S. Kadayifci, Peace and Conflict Resolution in Islam (Lanham: New York, Oxford: University Pressof America, inc, 2001), 145; Abdul Aziz Dahlan (ed), Ensiklopedi Hukum Islam (Jakarta: Ichtiar Baru Van Hoeve, 1996), Cet V, 1750. 
terorganisir, setiap ada persengketaan mengenai hak milik, hak waris dan hak-hak lainnya sering kali diselesaikan melalui bantuan juru damai atau wasit yang ditunjuk oleh masing-masing pihak yang berselisih. ${ }^{24}$ Perselisihan yang sering terjadi dikalangan Arab-Jahiliyah yaitu dalam masalah "al-Munâfarah wa al-Mufâkharah" (saling membagakan diri atau kelompoknya masing-masing) hingga tidak jarang berbuntut pada jatuhnya peperangan diantara suku-suku. ${ }^{25}$ Pendapat ini dikuatkan pula oleh al-Tharâbulasî, pengarang "muîn al-hukâm” yang mengkategorikan tahkîm sebagai salah satu jenis al-shulh. ${ }^{26}$

Tahkîm dikenal juga khususnya dalam persoalan hubungan rumah tangga. Kasus yang secara jelas disarankan mekanisme tahkîm adalah syiqâq, ${ }^{27}$ Konflik antara suami istri. Syiqâq ini terjadi akibat nusyuz, baik yang dilakukan oleh pihak suami atau pihak istri. Apabila konflik suami istri telah mengakibatkan terjadinya kekerasan, maka tahkîm mekanisme penyelesaiannya. Jadi, Al-Mâwardi cenderung untuk menegaskan bahwa sûlhu dalam hubungan kelurga diperuntukkan untuk konflik nonkekerasan, sedangkan tahkîm untuk konflik yang mengandung kekerasan, yang disebut pula dengan syiqâq. ${ }^{28}$

Dalam tradisi Islam sendiri telah dikenal badan hakâm yang sama artinya dengan arbitrase. ${ }^{29}$ Hanya saja arbitrase Islam pada waktu itu bersifat ad hoc. Lembaga hakâm yang bersumber dari syari'at Islam, putusannya didasarkan pada islah (perdamaian) dengan sifat peradilannya yang cepat, murah, final dan mengikat. Pada awalnya perkara yang ditangani tidak terbatas hanya dalam masalah perdata. Namun akhirnya disepakati masalah yang ditangani adalah terbatas pada masalah amwal

${ }^{24} \mathrm{Nj}$. Coulson, A History of Islamc Law (Edinburg: Edinburg University Press, 1991), h. 10.

${ }^{25}$ Abdul Aziz Muhammad Azzâm dan Abdul Wahhâb al-Sayyid Hawâs, al-Nizhâm al-Qadhầ fí al-Islàm (t.tp: Maktabah al-Rîsâlah, 1997), h. 213.

26 'Ala'uddin Abî al-Hasan Alî ibn Khalîl al-Tharâbulasî Muîn al-Hukkâm fî ma Yataraddadu baina al-Khasmain min al-Ahkâm (Kairo: Muhammad Mahmûd al-Halabî, 1973), cet. II, 35.

${ }^{27}$ Syiqâq adalah perbedaan dan permusuhan yang membuat kedua belah pihak suami-isteri berada dalam posisi berseberangan akibat permusuhan antara keduanya. Muhammad Alî Al-Sâbûnî, Tafsîr Âyât al-Ahkâm min al-Qur'ân (Beirut: Dâr Ibn Abbûd, 2004), I, h. 335.

${ }^{28} \mathrm{Abu}$ al-Hasan 'Alî al-Mawardi, al-Hâwî al-Kabîr (Syarh Mukhtasar al-Muzannî) (Beirut: Dâr al-Kutub al-'Ilmiyyah, 1999), XII, h. 200-201.

${ }^{29}$ Istilah "arbitrase" (arbitrage [Belanda; Perancis], arbitration [Inggris], schiedspruch [Jerman\}, berasal dari bahasa Latin yaitu arbitrase artinya kekuasaan untuk menyelesaikan sesuatu menurut kebijaksanaan atau perdamaian. James et. All, (editor), The Oxford English Dictionary; A New English Dictionary on Historical Principles (oxford: Clarendon Press, 1978), Vol. I, Cet. 1, h. 425. 
(harta benda). Pemantapan institusi hakam dalam sejarah hukum Islam terlebih lagi berlangsung setelah fikih muamalah berkembang pesat. ${ }^{30}$

Secara teoritis penyelesaian perkara melalui mediasi di Pengadilan Agama memiliki tujuan dan cara untuk mencapai maksud-maksud mewujudkan kemaslahatan manusia sesuai dengan nilai-nilai syari'ah. Ahmad Fathi Bahansi mengatakan bahwa pengaturan kemaslahatan manusia berdasarkan syara'. Paling tidak, siyâsah syar'iyyah terkait dengan kemestian untuk selalu mewujudkan keadilan, rahmat kemaslahatan dan hikmah. ${ }^{31}$ Dalam definisi Ibn Aqil, yang dikutip oleh ibn Qayyim, siyasah adalah "segala Perbuatan yang membawa manusia lebih dekat pada kemaslahatan dan lebih jauh dari kemafsadatan, sekalipun Rasulullah tidak menerapkannya dan (bahkan) Allah SWT tidak menentukannya". ${ }^{32}$ Untuk kepentingan itu, Abu Ishaq al-Syathibi mengusulkan teori maqâsîd al-Syarîah ini memberikan penekanan pada aspek kemaslahatan atau kesejahteraan umat manusia. Al-Syatibi membagi maqâsîd al-syar'ah menjadi tiga, yakni primer/keharusan (darûriyyat), kebutuhan (hajjiyat), penghias (tahsiniyy $\hat{u}$ ). Tahsiniyyât dalam kaidah usul fiqh dikenal dengan sebutan maslahah mursalah, yakni "pembinaan (penetapan) hukum (istinbât al-hukm) berdasarkan maslahat (kebaikan, kepentingan), di mana maslahat ini tidak ada ketentuannya dari syara', baik yang menegaskannya (itibâr) maupun mengabaikannya (ilghâ'), namun ia merupakan sifat-sifat yang sesuai dengan kehendak-kehendak dan tujuan-tujuan syâri, dimana hukum yang dihasilkannya itu merupakan penarikan kemaslahatan (jalb al-maslahâh) dan/atau penghindaran kemafsadatan (daf'mafsadah) dari manusia." ${ }^{33}$ Dalam konteks ini, model mediasi yang dikembangkan oleh Pengadilan Agama padadasarnya adalah langkah politik hukum (siyâsah syariyyah) dalam rangka mewujudkan kemaslahatan masyarakat. Dalam hal ini, kemaslahatan umum (maslahah 'ammah), yang dijadikan sebagai salah satu dari sumber syari'at dalam mazhab Maliki, harus memenuhi tiga syarat, yaitu: kemaslahatan umum itu bukan hal-hal yang berkenaan dengan ibadah; kemaslahatan umum harus selaras (in harmony with)

${ }^{30}$ Ahmad Dimyati, Sejarah Lahirnya BAMUI, salah satu tulisan dalam Arbitrase Islam di Indonesia (Jakarta: BAMUI \& BMI, 1994), h.193.

${ }^{31}$ Ahmad Fathi Bahansi, Al-Siyasah al-Jinaiyyah fi al-Islamiyah, Dar al-Arubah, tt, h.61.

${ }^{32}$ Ibn Qayyim al-Jauziyah, I'lam al-Muwaqqiin 'an Rabbil Alamîn, Dar al-Jayl, Beirut, tt, III, h.16.

${ }^{33}$ Wahbah al-Zuhaili, Ushul al-Figh al-Islamî (Beirut: Dâr al-Fikr, 1986), Jilid 2, h. 757 - 767. 
dengan jiwa syari'ah dan tidak boleh bertentangan dengan salah satu sumber syari'ah itu sendiri; dan kemaslahatan umum itu haruslah merupakan sesuatu yang esensial ${ }^{34}$ (diperlukan) dan bukan hal-hal yang bersifat kemewahan. ${ }^{35}$ Umar Shihab menyebutkan empat kriteria, yaitu: Pertama, bertujuan menyempurnakan maksud-maksud syari'ah; Kedua, penggunaannya harus sederhana (seimbang) dan dapat diterima oleh akal (logis); Ketiga, penggunaannya bertujuan mengatasi kesulitan; dan Kempat, penggunaannya untuk kepentingan umum. ${ }^{36}$

Eugan Ehrlich, yang di dukung oleh Lawrence M. Friedman, Roscoe Pound dan Muchtar Kusumaatmadja. Ehrlich menyatakan bahwa hukum positif hanya akan efektif apabila selaras dengan hukum yang hidup dalam masyarakat, yang dalam istilah antropologi dikenal sebagai pola-pola kebudayaan (culture patern). ${ }^{37}$ Jika ingin diadakan perubahan hukum, atau membuat suatu Undang-undang, agar hukum atau Undang-undang yang dibuat itu dapat diterima dan berlaku secara efektif di dalam kehidupan masyarakat, maka suatu hal yang patut diperhatikan adalah hukum yang hidup (living law) dalam masyarakat. ${ }^{38}$ Jika hal itu tidak mendapat perhatian, maka akibatnya hukum itu tidak akan berlaku efektif, bahkan akan mendapat tantangan. ${ }^{39}$ Menurut Friedman pada inti sistem hukum adanya aturan yang benar-benar berjalan. Karena salah satu fungsi sistem hukum berkaitan dengan perilaku mengontrol, yaitu memerintahkan orang

${ }^{34}$ Esensial adalah sesuatu yang berkaitan dengan tujuan syari'ah (maqashidu al-Syari'ah) yang pada intinya terangkum dalam mabadi' al-Khamsah. Yakni memelihara agama, jiwa, akal, keturunan, dan harta. Lihat Abu Yazid, Islam Akomodatif Rekonstruksi Pemahaman Islam Sebagai Agama Universal (Yogyakarta: LkiS Yogyakarta, 2004), h.77.

${ }^{35}$ Muhammad Tahir Azhary, Negara Hukum Suatu Studi tentang Prinsip-prinsipnya Dilihat dari Segi Hukum Islam, Implementasinya pada Periode Negara Madinah dan Masa Kini (Jakarta: Bulan Bintang, 1992), h.7.

${ }^{36}$ Ketutwirawan, Teori Receptio in Complexu, www.ketutwirawan.com.

${ }^{37}$ Soejono Soekanto, Pokok-pokok Sosiologi Hukum (Jakarta: Rajawali, 1991), h. 36.

${ }^{38}$ sistem hukum yang dikemukakan Lawrence M. Fridman tersebut adalah, Pertama, struktur hukum (Legal Struktur), berkaitan dengan bentuk atau format yang mencakup unsur-unsur kelembagaan, penegakan, pelayanan, pengelolaan hukum pada umumnya. Kedua, subtansi hukum (Legal Subtance), mencakup berbagai aturan formal, aturan-aturan yang hidup dalam masyarakat (the living Law) dan berbagai produk yang timbul akibat penerapan hukum. Tiga, budaya hukum (Legal Cultur), berkenaan dengan sikap terhadap hukum, sikap tersebut berkaitan dengan sikap budaya pada umumnya, karenanya akan menyatukan hal-hal seperti keyakinan (bilef), nilai serta ide dan harapan-harapan (expectation). Lawrence M. Friedman, Law and Society (New Jersey: Printice Kall, 1977),h. 6-7.

${ }^{39}$ C.S.T. Kansil, SH, Latihan Ujian Pengantar Ilmu Hukum Untuk Perguruan Tinggi (Jakarta: Sinar Grafika, 2007, Cet. VI),h. 80-81. 
apa yang harus dan jangan dilakukan, dan sistem hukum itu menjunjung perintah-perintahnya dengan paksa. ${ }^{40}$ Selain itu, keputusan yang diambil hakim sebagai mediator dalam mendamaikan pihak-pihak yang berperkara merupakan keputusan yang efektif, yang merupakan salah satu dari teori hukum ${ }^{41}$ dan tujuan hukum 1) kepastian hukum, 2) keadilan hukum, dan 3) kemanfaatan. ${ }^{42}$

Untuk menganalisis mengapa suatu perkara berhasil diselesaikan melalui mediasi atau tidak, dikemukakan oleh Lucy V Kazt. Yaitu keberhasilan proses penyelesaian sengketa alternativ melalui mediasi dikarenakan adanya "equitable and legal remidies" yang memberikan adanya kesederajatan yang sama dan penggantian kerugian secara hukum yang harus dihormati oleh para pihak. Para pihak mempunyai keyakinan bahwa penyelesaian sengketa melalui mediasi akan mendapat remedy for damages bagi mereka dengan win-win solution dan bukan win lose solution. Di sini, para pihak "sama-sama menang" tidak saja dalam arti ekonomi atau keuangan, melainkan termasuk juga kemenangan moril dan reputasi (nama baik dan kepercayaan). ${ }^{43}$

Penyelesaian sengketa dengan musyawarah ${ }^{44}$ merupakan budaya

${ }^{40}$ Lawrence M. Friedman, Law and Society (New Jersey: Printice Kall, 1977),h. 6-7.

${ }^{41}$ Teori efektivitas adalah teori hukum yang menyatakan bagaimana orang seharusnya bertingkah laku atau bersikap tindak sesuai dengan tata kaidah hukum, hanya apabila tata kaidah hukum secara menyeluruh efektif. Purnadi Purbacaraka dan Soerjono Soekanto, Perihal Kaidah Hukum, 23. Teori yang dikemukakan puka oleh Hans Kelsen tersebut, menimbulkan ancaman yang lebih keras lagi terhadap ajarannya yang murni tentang hukum sehingga ia tidak lagi melanjutkan masalah efektivitas karena menyangkut masalah politik yang harus ditinjau secara sosiologis, Purnadi Purbacaraka dan Soerjono, Perihal Kaidah Hukum. h.24.

${ }^{42}$ Achmad Ali, Menguak Tabir Hukum, 72. Achmad Ali mengatakan bahwa aliran Ilmu Hukum Positif/Yuridis-Dogmatik bersumber dari pemikiran positivistis di dunia hukum, yang cenderung melihat hukum sebagai sesuatu yang otonom, yang mandiri, karena hukum hanya kumpulan aturan. Tujuan hukum menurut aliran ini adalah kepastian hukum. Apeldoorn mengatakan bahwa keadilan menuntut supaya tiap-tiap perkara harus ditimbang sendiri. Keadilan melarang "menyamaratakan". Menurut Van Apeldoorn, tujuan hukum ialah mengatur pergaulan hidup secara damai. Van Apeldoorn mengatakan bahwa keadilan menuntut supaya tiap-tiap perkara harus ditimbang sendiri. Hukum melarang "menyamaratakan". Van Apeldoorn, Pengantar Ilmu Hukum, h.13.

Lucy V. Kazt, "Enforcing an ADR Clause-Are Good Intention All You Have ?,"American Bussiness Law Journal 575. (1988), h. 588

${ }^{43}$ Lucy V. Kazt, "Enforcing an ADR Clause-Are Good Intention All You Have ?," American Bussiness Law Journal 575. (1988), h. 588

${ }^{44}$ Konsep musyawarah sesuai dengan teori huku pembangunan yang disampaikan oleh Muchtar Kusumaatmadja, yang diadopsi dari konsep hukum yang digagas Roscoe Pond yaitu "Lawa 
asli Indonesia tanpa perlu proses pengadilan yang merugikan kedua belah pihak. Oleh karena itu, musyawarah secara mediasi mempunyai peluang yang besar untuk dikembangkan di Indonesia sesuai dengan adat ketimuran yang masih mengakar, masyarakat lebih mengutamakan menjalin hubungan silaturrahmi antar keluarga atau hubungan dengan rekan bisnis daripada keuntungan sesaat apabila timbul sengketa. ${ }^{45}$ Masyarakat Indonesia lebih mengutamakan harmoni komunal atas kepentingan individu. Walaupun satu pihak merasa dirinya lebih benar dalam substansi perkara, namun sikap dan penanganan masalah yang tidak tepat bisa membuat pihak tersebut diminta untuk mengalah demi menjaga keselarasan dan ketentraman masyarakat. ${ }^{46}$

Mediasi merupakan pilihan aman dalam sebuah arbritase, sebagaimana dikatakan oleh Mahdi Zahraa dan Nora A. Hak. ${ }^{47}$ Menurutnya dalam proses mediasi menggunakan dua pendekatan, yaitu menekankan pentingnya kualifikasi dan peran mediator, dan menekankan proses berjalannya mediasi. Pendapat tersebut juga diperkuat Aida Othman ${ }^{48}$ yang menyatakan bahwa mediasi lebih fleksibel dalam proses dan hasilnya dibanding dengan litigasi di pengadilan. Mediasi dipandang lebih mengedepankan hak individu. Penanganan perkara dipengadilan seorang hakim berupaya memediasikan para pihak untuk mencari kemungkinan adanya perdamaian antara keduanya. Namun untuk memediasikan permasalahan keluarga dibutuhkan seorang mediator yang dipercaya masyarakat memiliki kapasitas untuk menyelesaikan perkara. Sebab kendala terbesar dari implementasi mediasi dilapangan adalah terkait dengan aspek emosional para pihak. Dengan kata lain, kesuksesan mediasi bergantung terhadap kemampuan mediator menghadapi pihak yang berperkara. ${ }^{49}$

as Tool Social Engineering" (hukum sebagai alat sosial. Mochtar Kusumatmadja, Konsep-konsep Hukum dalam Pembangunan (Bandung: Alumni, 2002), h 14.

${ }^{45}$ Fatahillah A. Syukur, "Behind Closed Doors: Family Dispute Settlement in Court Annexed Mediation in Indonesia", dalam Jurnal Contribution Maters, ed PPIA, Perhimpunan Pelajar Indonesia Australia (Sydney: Australia, 2010), h. 154

${ }^{46}$ John S.K. Ng, "The Four Faces of Face: Implication for Mediation", dalam Jurnal Asian Perspective on Mediation, Eds Lee, J. Dan Hwee, T.H., Academy Publihing, Singafore, 2009, h.71.

${ }^{47}$ Mahdi Zahraa dan Nora A. Hak, "Tah\{kîm (Arbitration) In Islamic Law Within The Context of Family Dispute", dalam Journal Arab Law Quarterly (Leiden: BRILL, 2006), Vol. 20 No. 1, h. 41.

${ }^{48}$ Aida Othman, "And Amicable Settlement in Best: Sulh\{ dan Dispute Resolution In Islamic Law" dalam Journal Arab Law Quarterly (Leiden: BRILL, 2006), Vol. 20 No. 1, h. 90.

${ }^{49}$ Emily M. Brown, "Emotional Dynamics or Couples in Mediation." Dalam James C 
Upaya mediasi di pengadilan terhadap sengketa keluarga diatur dalam Pasal 39 Undang-undang No. 1 Tahun 1974, Pasal 56 Undang-undang Nomor 7 Tahun 1989 yang terakhir diubah dengan Undang-undang Nomor 50 Tahun 2009, Pasal 115, 131, 143, dan 144 KHI, serta Pasal 32 PP No. 9 tahun 1975.Ketentuan yang dimuat dalam pasal-pasal ini meminta hakim untuk berusaha mendamaikan para pihak sebelum perkara mereka diputuskan. Upaya damai tidak hanya dilakukan hakim pada saat permulaan sidang, tetapi juga pada setiap sidang. Hakim dituntut selalu menawarkan uapaya damai dalam setiap proses persidangan, karena penyelesaian perkara melalui kesepakatan damai jauh lebih baik, bila dibandingkan dengan vonis hakim. Pentingnya upaya damai dalam penyelesaian sengketa keluarga, mengharuskan hakim mengajak atau menghadirkan pihak terdekat atau keluarganya untuk diminta keterangan. Hakim dapat meminta bantuan dari keluarga terdekat para pihak, agar mereka dapat menempuh jalur damai, dan bila upaya ini gagal maka hakim menyelesaikan perkara tersebut melalui putusan.

Adapun urgensi dan motivasi dari mediasi terhadap perkara di pengadilan agar pihak-pihak yang berperkara menjadi damai dan tidak melanjutkan perkaranya dalam proses pengadilan. Apabila ada hal-hal yang mengganjal yang selama ini menjadi masalah, maka harus diselesaikan secara kekeluargaan dengan musyawarah mufakat. Adapun tujuan mediasi untuk mencapai perdamaian antara pihak-pihak yang berperkara yang biasanya sangat sulit untuk mencapai kata sepakat biasanya menjadi cair apabila dipertemukan dengan difasilitasi oleh seorang atau lebih mediator untuk memfilter persoalan-persoalan agar menjadi jernih dan pihak yang berperkara mendapatkan kesadaran akan pentingnya perdamaian antara mereka. $^{50}$

Sesuai dengan maknanya, mediasi berarti menengahi. Seorang mediator tidaklah berperan sebagai judge yang memaksakan pikiran keadilannya, tidak pula mengambil kesimpulan yang mengikat seperti arbitrer tetapi lebih memberdayakan para pihak untuk menentukan solusi

Hansen, and Grebe, Sarah Childs. Divorce and Family Mediation (United State of America: An Aspen Publication, 1985), h. 81

${ }^{50}$ Mediation has generally proven to be more cost effective and less time consuming than litigation. Lawrence R. Freedman \& Michael L. Prigoff, "Confidentiality in Mediation: The Need for Protection”, Ohio ST.J. On Dispute Resolution, 1986, h. 37. 
apa yang mereka inginkan. Mediator mendorong dan memfasilitasi dialog, membantu para pihak mengklarifikasi kebutuhan dan keinginan-keinginan mereka, menyiapkan panduan, membantu para pihak dalam meluruskan perbedaan-perbedaan pandangan dan bekerja untuk suatu yang dapat diterima para pihak dalam penyelesaian yang mengikat. Jika sudah ada kecocokan di antara para pihak yang bersengketa lalu dibuatkanlah suatu memorandum yang memuat kesepakatan-kesepakatan yang telah dicapai. ${ }^{51}$ Menjadikan pemeriksaan di Pengadilan berjalan dengan cepat, sederhana dan murah sesuai dengan Pasal 4 Ayat (2) Undang-Undang No. 4 Tahun 2004 tentang Ketentuan-ketentuan Pokok Kekuasaan Kehakiman. Paragrapparagrap ini mencoba menjelaskan tugas hakim untuk mendamaikan para pihak, kelemahan hakim untuk mendamaikan para pihak dan keberhasilan perdamaian tergantung itikad baik para pihak.

Penyelesaian perkara oleh hakim mediator di Pengadilan Agama menggunakan pendekatan problem solving merupakan suatu usaha untuk menemukan jalan keluar win-win solution. Salah satu fungsi mediator menerapkan pendekatan ini bila mereka memiliki perhatian yang besar terhadap aspirasi pihak-pihak yang berperkara dan menganggap bahwa jalan keluar menang sangat mungkin dicapai. Oleh karena itu, pendekatan problem solving ${ }^{52}$ yang dilakukan mediator sering disebut sebagai mediasi fasilitatif yang bertujuan untuk menegosiasikan kebutuhan dan kepentingan para pihak yang berperkara. Dalam teknik mediasi fasilitatif ini mediator harus dapat memimpin proses mediasi. Mengupayakan dialog yang konstruktif antara para pihak, serta meningkatkan upaya-upaya negosiasi dan mengupayakan kesepakatan. ${ }^{53}$

Berkaitan hal tersebut di atas, mediator berdasarkan PerMA No 01 tahun 2008 tentang mediasi adalah pihak netral yang membantu para pihak dalam proses perundingan guna mencapai berbagai kemungkinan penyelesain sengketa tanpa menggunakan cara memutus atau memaksakan

${ }^{51}$ Gede Widhiana Putra, Mediasi, Jakarta, 22 Mei 2006.

52 Mengingat dalam proses mediasi adalah untuk membantu para pihak yang berperkara menemukan solusi mereka sendiri, maka pendekatan problem solving dalam mediasi sesuai diterapkan di Pengadilan untuk mencapai kesepakatan yang ditentukan oleh pihak yang berperkara, Pusdiklat MA-Ri, Mediasi dan Perdamaian MARI, h.154.

${ }^{53}$ Laurence Boulle, Mediation: Principles, Process, Practice, (Australia: Lexis Nexis Butterworths, 2005), h. 45. 
sebuah penyelesaian. ${ }^{54}$ Ciri-ciri dari mediator, sebagaimana tercermin dalam rumusan Pasal 1 butir 5 diantaranya: 1. Netral, 2. Membantu para pihak dan 3. tanpa menggunakan cara memutus atau memaksakan penyelesaian. Jadi, peran hakim yang menjalankan fungsi sebagai mediator hanyalah membantu para pihak dengan cara tidak memutus atau memaksakan pandangan atau penilaiannya terhadap masalah selama proses mediasi berlangsung kepada para pihak yang berperkara. Pendekatan problem solving melalui mediasi fasilitatif sangat sesuai bagi hakim untuk menjalankan fungsinya sebagai mediator yang harus memfasilitasi dan membantu kedua belah pihak yang berperkara. ${ }^{55}$

Dalam pendekatan problem solving ini, mediator membantu para pihak yang berperkara untuk saling mengerti dan bekerjasama yang dapat diterima oleh kedua belah pihak. ${ }^{56}$ Selain itu, mediator mencoba untuk memperjelas dan memperbaiki komunikasi antara para pihak tanpa ikut campur dalam proses mereka, tetapi menawarkan nasehat secara rutin para arah proses yang bermakna. ${ }^{57}$ Mediator dalam teknik fasilitatif menghindari para pihak tergelincir dari proses tawar menawar yang terus meningkat (incremental bergaining). Dengan terus menekankan tujuan para pihak dengan menjelaskan kepentingan bersama atau yang saling menguntungkan, mendorong penciptaan kuat nilai (value creation) dan mengajukan secara kreatif opsi penyelesaian..$^{58}$

Mediator tidak menyarankan jalan keluar atau mengarahkan hasilnya kepada suatu penyelesaian pada tingkatan yang wajar atas perselisihan tersebut, tetapi akan membantu para pihak untuk menilai kembali dasar situasi dan mendapatkan kesepakatan mereka sendiri, mediator biasanya seorang ahli dalam proses dan teknik mediasi dan mungkin memiliki pengetahuan yang terbatas dalam permasalahan yang diperkarakan, karena

${ }^{54}$ Lihat pasal 1 ayat (6) PerMA Nomor 01 Tahun 2008.

55 Zena Zumeta, "A Facilitative Mediator Responds," Journal of Dispute Resolution, 2000, Diakes pada tanggal 6 Juni 2013, h. 335

${ }^{56}$ Carol Weigler, Jerald Weigler, "Facilitative Mediation," Journal Oregon State Bar 63, (Juni, 2003), 27. Diakses pada tanggal 6 Juni 2013.

${ }^{57}$ Karen K. Klein, "A Judicial Mediator's Perspective: The Impact of Gender on Dispute Resolution: Mediation As a Different Voice," (North Dakota, Journal Law Review 81, (2005), h.775.

${ }^{58}$ Pusdiklat MA-RI, Mediasi dan Perdamaian, h. 153. Kepuasan para pihak dapat tercapai pemecahan yang lebih kreatif dengan menggunakan mediator di pengadilan, Richard Birke, "Mandating Mediation of Money: The Implications og Enlarging the Scope of Domestic Relations From Custody to Full Service," Journal Willamete Law Review, 1991, h. 485 - 491. 
prosesnya lebih ditujukan kepada kebutuhan dan kepentingan para pihak terkait. Mediasi berdasarkan kepentingan ini dapat mengangkat masalah, memecahkan dengan pendekatan yang memberi semangat para pihak untuk bernegosiasi dalam masa sidang pengadilan. ${ }^{59}$

\section{Tipologi Mediator}

Mediator adalah pihak ketiga yang impartial, berperan sebagai perantara yang menolong para pihak bersengketa dalam usaha mencari penyelesaian berupa kesepakatan atas permasalahan yang terjadi. Peraturan MA No. 01 Tahun 2008, mendefinisikan mediator sebagai pihak netral yang membantu para pihak dalam proses perundingan guna mencari berbagai kemungkinan penyelesaian sengketa tanpa menggunakan cara memutus atau memaksakan sebuah penyelesaian. Secara umum berdasarkan relasi antara mediator dan para pihak yang bersengketa, Christopher W. Moore dalam tulisannya The Mediators Process; Practical Strategies for Resolving Conflict membagi tipe mediator sebagai berikut: ${ }^{60}$

Pertama, Social Network Mediator (Mediator Jaringan Sosial). Orang yang dipilih sebagai mediator dalam suatu proses penyelesaian sengketa karena ia memiliki relasi dengan salah satu pihak atau para pihak yang bersengketa. Relasi yang ada antara mediator tipologi ini dengan para pihak bukanlah relasi yang baru saja tercipta karena adanya sengketa, tetapi merupakan relasi yang telah ada sebelumnya dan akan terus ada tanpa dipengaruhi akhir dari penyelesaian sengketa yang sedang terjadi. Mediator tipologi ini tidak harus netral, artinya ia dapat berasal dari salah satu pihak, namun diharapkan dia bersikap adil dan dipercaya. Pada umumnya mediator tipologi ini berasal dari teman pribadi para pihak, tetangga, rekan kerja/ rekan bisnis, atau para pemuka agama seperti pendeta atau ulama, atau dapat juga berasal dari seseorang yang dihormati atau dituakan di tengah-tengah suatu komunitas sosial yang tentunya juga sudah dikenal baik oleh para pihak. ${ }^{61}$

\footnotetext{
59 Zena Zumeta, "A Facilitative Mediator Responds, h. 337.

${ }^{60}$ Christopher W. Moore, The Mediation Process Practical Strategies for Resolving Conflict, $3^{\text {rd }}$ edition,

${ }^{61}$ Materi Pelatihan Mediator, Dalam Rangka Pelaksanaan PerMa RI Nomor 2 Tahun 2003, Kerjasama antara Pusat Penelitian dan Pengembangan MARI dengan Indonesian Institute For Conflict Transformation, didukung oleh The Asia Foundation Tahun 2004, h. 6.
} 
Kedua, Lederach menggambarkan mediator tipologi ini dengan menggunakan istilah yang berasal dari "confianza mediation": "seseorang dipilih sebagai mediator didasarkan atas kepercayaan, dimana kita mengenal dia dengan baik dan percaya bahwa orang tersebut dapat menjaga kerahasiaan kita." ${ }^{62}$ Mediator jaringan sosial memiliki kewajiban secara pribadi untuk menolong para pihak menyelesaikan sengketa yang ada sebagai seorang teman, keinginan untuk membantu para pihak ini didasarkan atas relasi pribadi yang dimilikinya dengan para pihak. Mediator jaringan sosial ini juga akan terus berusaha menjaga keharmonisan hubungan yang ada di antara para pihak.

Ketiga, Authoritative Mediator (Mediator Otoritatif), yaitu mediator yang memiliki hubungan otoritatif dengan para pihak yang bersengketa yang menyebabkan ia memiliki posisi yang kuat atau berpengaruh sehingga berpotensi mempengaruhi para pihak dalam menentukan hasil akhir atau kesepakatan dari sengketa yang ada. Hubungan otoritatif ini ada sebelum dan setelah sengketa berlangsung, maksudnya ialah hubungan yang ada tidak dipengaruhi oleh sengketa yang timbul. Mediator tipologi ini mencari penyelesaian sengketa dengan mengupayakannya bersama dengan para pihak dalam lingkup mandat atau kewenangannya. Selama menjalankan peran sebagai mediator ia tidak menggunakan kewenangan atau pengaruhnya, karena berdasarkan pada keyakinan atau pandangan bahwa pemecahan yang terbaik terhadap sebuah kasus bukanlah ditentukan oleh sisinya sebagai pihak yang berpengaruh atau berwenang, tetapi harus dihasilkan oleh upaya-upaya para pihak yang bersengketa sendiri. Namun jika pada akhirnya para pihak tidak dapat menemukan kata sepakat di akhir proses mediasi, maka mediator otoritatif berwenang dan memiliki otoritas untuk mengambil keputusan bagi para pihak. Tipologi mediator otoritatif ini dapat dibagi lagi menjadi beberapa kualifikasi, yakni: Benevolent Mediator, Administrativel Managerial Mediator, dan Vested Interest Mediator. Tipologi mediator otoritatif ini lebih sering dilakukan oleh aparat pemerintah.

Keempat, Mediator mandiri adalah mediator yang dianggap paling baik atau profesional bila dibandingkan dengan dua tipe mediator diatas karena mediator mandiri tidak memiliki hubungan, baik secara langsung maupun

${ }^{62}$ Jacob Bercovitch, Resolving International Conflicts: The Theory and Practice of Mediation, Lynne Rienner Publishers,1996), 
tidak langsung dengan para pihak yang bersengketa. Pada umumnya orang-orang yang menjadi mediator mandiri bersifat profesional. Dia akan melayani para pihak sepenuhnya dengan menggunakan pendekatan sukarela dan tidak mempunyai sumberdaya untuk memantau pelaksanaan kesepakatan. ${ }^{63}$

\section{Penutup}

Perkembangan mediasi dalam penyelesaian sengketa perdata Islam memberikan memberikan kesan bahwa masyarakat muslim dalam penyelesaian perdata Islam diserahkan kepada Pengadilan Agama. Mediasi merupakan proses perundingan pemecahan masalah dimana pihak luar yang tidak memihak (impartial) dan netral bekerja dengan pihak yang bersengketa untuk membantu mereka memperoleh kesepakatan perjanjian dengan memuaskan. Berbeda dengan hakim atau arbiter, mediator tidak mempunyai wewenang untuk memutuskan sengketa antara para pihak. Namun dalam hal ini para pihak menguasakan kepada mediator untuk membantu mereka menyelesaikan masalah diantara mereka. Asumsinya bahwa pihak ketiga akan mampu mengubah kekuatan dan dinamika sosial hubungan konflik dengan cara mempengaruhi tingkah laku pribadi para pihak dengan memberikan pengetahuan atau informasi yang lebih efektif. Dengan demikian, mediator dapat membantu para pihak untuk menyelesaikan persoalan-persoalan yang dipersengketakan.

Pelaksanaan mediasi di Pengadilan Agama memberikan nilai-nilai positif dalam penyelesaian perselisihan, seperti pentingnya penghormatan terhadap orang lain, kehormatan, kejujuran, keadilan, saling timbal balik, partisipasi individual, kesepakatan dan pengendalian para pihak. Nilainilai mana selanjutnya meng-counter sistem nilai yang berlaku dalam penyelesaian perkara secara litigasi, seperti proses adversial, tidak personal, pengendalian oleh pengacara, dan perintah otoritatif peraturan. Dan bagi Pengadilan Agama yang menangani perkara-perkara keluarga (al-abwal al-syakhshyiah) yang didominasi oleh perkara-perkara perceraian, mediasi memberikan keuntungan dengan semakin bervariasinya bentul-bentuk upaya damai yang dapat ditawarkan untuk menghindari terjadinya perceraian. Sejauh ini telah ada upaya damai yang dilakukan oleh hakim

${ }^{63}$ Joni Emerzon, Alternatif, h.77-78 
saat dan selama memeriksa perkara, upaya damai oleh hakim yakni pihak keluarga, khusus dalam perkara syiqaq. Dengan adanya mediasi, maka upaya hukum sebagai building block penting sebelum perceraian benarbenar terjadi menjadi semakin kokoh.

\section{Pustaka Acuan}

Abdul Aziz Said, Nathan C. Funk, Ayse S. Kadayifci, Peace and Conflict Resolution in Islam Lanham: New York, Oxford: University Pressof America, inc, 2001.

Dahlan, Abdul Aziz, (ed), Ensiklopedi Hukum Islam Jakarta: Ichtiar Baru Van Hoeve, 1996, Cet V, 1750.

Manan, Abdul, Peran Peradilan Agama dalam Perspektif Pembaharuan Hukum Islam: Studi Kasus Terhadap Putusan-putusan dilingkungan Peradilan Agama DKI Jakarta Medan: Universitas Sumatera Utara, 2004.

Muhammad Azzam, Abdul Aziz, dan Abdul Wahhab al-Sayyid Hawas, al-Nizham al-Qadhai fi al-Islam, t.tp: Maktabah al-Risalah, 1997.

'Ali al-Mawardi, Abu al-Hasan, al-Hawi al-Kabir (Syarh Mukhtasar alMuzanni) Beirut: Dar al-Kutub al-'Ilmiyyah, 1999.

Dimyati, Ahmad, Sejarah Lahirnya BAMUI, salah satu tulisan dalam Arbitrase Islam di Indonesia Jakarta: BAMUI \& BMI, 1994.

Ahmad ibn Muhammad ibn al-Maqri al-Fayumi,, Kitab Misbah al-Munir fi Gharib al-Syarh al-Kabir li al-Rafi'i, Kairo: al-Mathba'at al-Amiriyyah li Wuzarat al-Ma'arif al-'Umumiyyah, 1968.

Anonimous, Buku komentar Peraturan Mahkamah Agung RI No. 01 Tahun 2008 tentang Pelaksanaan Mediasi di Pengadilan. Dibuat atas kerjasama MARI, Japan International Cooperation Agency (JICA) dan Indonesia Institute for Conflict Transformation (IICT), 2008.

Ala'uddin Abi al-Hasan Ali ibn Khalil al-Tharabulasi, Müin al-Hukkam $f i$ ma Yataraddadu baina al-Khasmain min al-Ahkam Kairo: Muhammad Mahmud al-Halabi, 1973.

Manan, Bagir, "Peran Sosok Hakim Agama sebagai Mediator dan Pemutus Perkara serta Kegamangan masyarakat terhadap Keberadaan lembaga Peradilan," sambutan Ketua Mahkamah Agung RI. Pada Serah Terima Ketua Pengadilan Tinggi Agama Medan. 22 Agustus 2003. 
Departemen Agama, Himpunan Putusan Pengadilan Tinggi Agama Jakarta:

Badan Peradilan Agama, 1982/1983.

Syakur, Fatahillah A. "Behind Closed Doors: Family Dispute Settlement in Court Annexed Mediation in Indonesia", dalam Jurnal Contribution Maters, ed PPIA, Perhimpunan Pelajar Indonesia Australia Sydney: Australia, 2010.

Muhammad Qasim, Hamzah, Manar al-Qari Sharh Sahih Bukhari, Juz III Beirut: Maktabah Dar al-Bayan, 1990.

Instruksi Presiden Nomor 1 Tahun 1991 tanggal 10 Juni 1991 dan keputusan Menteri Agama Nomor 154 Tahun 1991 tanggal 22 Juli 1991. Lihat Harun Alrasyid, ed. Himpunan Peraturan Perundangundangan Republik Indonesia Jakarta: PT. Ichtiar Baru Van Hoeve.

Wade, Jhon, Sekitar Mediasi, Jakarta: MARI, 2004.

Lawrence R. Freedman \& Michael L. Prigoff, "Confidentiality in Mediation: The Need for Protection”, Ohio ST.J. On Dispute Resolution, 1986.

Luis Ma’luf, al-Munjid fi al-Lughah wa al-A'lam, Beirut: Dar al-Masyriq, 1986.

Sa'id Abi Jaib, al-Qamus al-Fiqhi Lughatan wa istilahan, Damaskus: Dar al-Fikr, 1998.

Lucy V. Kazt, "Enforcing an ADR Clause-Are Good Intention All You Have ?,"American Bussiness Law Journal 575.1988.

Muhammad Ibn Husayn Ibn 'Ali al-Turi al-Qadiri al-Hanafi, al-Bahr alRaiq, Juz VII.

Muhammad Tahir Azhary, Negara Hukum Suatu Studi tentang Prinsipprinsipnya Dilihat dari Segi Hukum Islam, Implementasinya pada Periode Negara Madinah dan Masa Kini, Jakarta: Bulan Bintang, 1992.

Nj. Coulson, A History of Islamc Law,Edinburg: Edinburg University Press, 1991.

Percy R. Luney, Jr, “Traditions an Foreign Influences: Systems of Law in China and Japan," Dalam Journal Law and Contemporary Problems Caroline: Duke University School of Law, 1987, Vol. 52, No. 2.

Robert E. Margulies, "How To Win In Mediation" New Jersey Lawyer, The Magazine, 2002. 
Syahrizal Abbas, Mediasi Dalam Perspektif Hukum Syariah Hukum Adat dan Hukum Nasional Jakarta: Kencana, 2009.

Samir Aliyah, Sistem Pemerintahan Peradilan dan Adat Dalam Islam Jakarta: Khalifah, 2004.

Wahbah al-Zuhayli, al-Figh al-Islami wa Adillatuh, Juz VI.

Zainal Abidin Abubakar, Himpunan Peraturan Perundang-undangan dalam Lingkungan Peradilan Agama Surabaya: Pengadilan Tinggi Agama Surabaya. tth. 